УДК 343.13

DOI https://doi.org/10.32837/apdp.v0i90.3207

\author{
С. В. Давиденко, Д.О. Мавдрик
}

\title{
ПРОБЛЕМИ ВДОСКОНАЛЕННЯ ПРАВОВОГО РЕГУЛЮВАННЯ ПРОЦЕДУРИ ПРОВЕДЕННЯ ОБШУКУ СЛІДЧИМ, ДІЗНАВАЧЕМ, ПРОКУРОРОМ
}

Постановка проблеми. Аксіоматичним є те, що виконання завдань кримінального провадження, закріплених у статті 2 Кримінального процесуального кодексу України (далі - КПК), нерідко забезпечується застосуванням засобів державного примусу. Це, у першу чергу, пояснюється специфікою тих правових відносин, які виникають всупереч волі та бажаннюїх учасників. Дослідження змісту нормативних приписів чинного кримінального процесуального законодавства України, а також сучасна правозастосовна практика доводять, що одним із найбільш поширених засобів кримінального процесуального примусу є обшук, який, разом із тим, виступає ефективним способом отримання необхідної доказової інформації в ході досудового розслідування. Результати аналізу слідчої та судової діяльності вказують на недосконалість нормативно-правового регулювання процедури проведення обшуку, що викликає низку проблемних питань під час здійснення кримінального провадження. Неоднозначне тлумачення $\mathrm{i}$, як наслідок, застосування норм чинного КПК зумовили існування неоднорідної та, подекуди, суперечливої практики, що викликає надмірне розширення обсягу правового регулювання його окремих положень.

3 огляду на це зазначена слідча дія за своїм змістовним наповненням $є$ багатоаспектною та потребує комплексного дослідження, під час якого доцільно зупинитись на розгляді обмеженого кола проблем, що найчастіше виникають у практиці правозастосування.

Аналіз наукових досліджень та публікацій. Проблематиці нормативно-правового регулювання інституту обшуку за чинним КПК присвячена значна кількість наукових праць вітчизняних учених, зокрема, таких як: В.І. Галаган, О.В. Капліна, О.П. Кучинська, Л.М. Лобойко, Є.Д. Лук'янчиков, С.Л. Шаренко, В.Ю. Шепітько, О.Г. Шило, а також інших відомих правознавців. Отримані наукові здобутки стали вагомим внеском у розвиток доктрини кримінального процесу та підгрунтям формування новітньої правозастосовної практики у цій сфері діяльності.

Метою статті є дослідження нормативного змісту положень чинного кримінального процесуального закону, що регламентують порядок проведення обшуку, висвітлення актуальних проблем, які виникають у слідчій та судовій практиці, а також формулювання можливих шляхів удосконалення приписів чинного кримінального процесуального законодавства України з даної тематики.

Починаючи міркування в окресленому напрямі, відзначимо, що слідчі (розшукові) дії виступають основним елементом системи способів збирання доказів на стадії досудового розслідування. Обшук, як один із їх різновидів, є чи не найбільш дієвим інструментом формування доказової бази під час здійснення кримінального провадження. Згідно з положеннями чинного кримінального процесуального закону це також одна з небагатьох примусових слідчих дій, яка може бути

(C) С. В. Давиденко, Д. О. Мавдрик, 2021 
проведена без згоди осіб, які володіють обшукуваними об'єктами. Тому процедура обшуку детально регламентується відповідними статтями глави 20 КПК, що має назву «Слідчі (розшукові) дії», та нормативами статті 30 Конституції України.

Так, на думку Н. П. Черняк, обшук - це слідча (розшукова) дія, яка направлена на примусове обстеження ділянок місцевості, приміщень, тіла людини, iї одягу та особистих речей, що здійснюється в рамках кримінального процесуального закону уповноваженою на те особою при дотриманні гарантій прав і законних інтересів громадян і юридичних осіб з метою пошуку (виявлення) та вилучення (затримання) конкретних джерел доказової інформації (матеріальних об'єктів), які можуть мати значення для справи [1, с. 149]. Водночас фактичне проведення обшуку пов'язане із суттєвим обмеженням конституційних прав і свобод особи. Саме тому така процедура підлягає судовому контролю з боку слідчого судді, який виконує особливу роль у досудовому провадженні і виступає гарантом реалізації та дотримання конституційної засади недоторканності житла/іншого володіння.

Наведений підхід відповідає європейським стандартам у галузі прав людини та прецедентній практиці Європейського суду з прав людини (далі - ЄСПЛ). Так, у справі «Класс та інші проти Німеччини» від 1978 р. ЄСПЛ наголошує, що принцип верховенства права виходить, зокрема, із того, що втручання органів виконавчої влади у права людини має підлягати ефективному нагляду, який, як правило, повинна забезпечувати судова влада, це має бути судовий нагляд, який найкращим чином забезпечує гарантії незалежності, безсторонності та належної правової процедури [2]. Відтак проведення обшуку без ухвали слідчого судді визнається істотним порушенням вимог КПК і тягне за собою визнання такої слідчої дії незаконною, а отриманих доказів - недопустимими. Принагідно нагадаємо, що згідно з п. 1 ч. 2 ст. 87 КПК суд зобов'язаний визнати істотним порушенням прав людини і основоположних свобод здійснення процесуальних дій, які потребують попереднього дозволу суду, без такого дозволу або з порушенням його суттєвих умов.

У контексті сказаного відмітимо, що незрозумілості в питанні правового регулювання процедури обшуку додає норма кримінального процесуального закону щодо суб'єктів його проведення. Фактично до початку 2019 р. питання про суб'єктний склад осіб, які можуть проводити обшук, залишалось таким, що потребує належного правового врегулювання.

У зв'язку із цим на практиці часто виникало питання стосовно використання окремих процесуальних форм взаємодії слідчого, прокурора та співробітників оперативних підрозділів при проведенні обшуку. Крапку в означеному питанні поставив Верховний Суд, який у постанові від 29 січня 2019 р. (справа № 466/896/17) роз'яснив, що за змістом ч. 1 ст. 236 КПК виконання ухвали слідчого судді про дозвіл на обшук житла чи іншого володіння особи покладається особисто на слідчого чи прокурора і не може бути доручене в порядку п. 3 ч. 2 ст. 40 КПК відповідним оперативним підрозділам [3]. Вказане рішення було прийнято з метою забезпечення єдності судової практики через неоднакове розуміння та, відповідно, застосування окремих положень чинного КПК.

У цьому аспекті доцільно звернути увагу не певну недосконалість законодавчої техніки при конструюванні нормативного змісту ст. 236 КПК, зокрема, в частині 
суб'єктів виконання ухвали слідчого судді про надання дозволу на проведення обшуку. Вважаємо, що не можна цілком погодитись із думкою М.В. Комарової про те, що у ст. 236 КПК України наголошується на виключному праві слідчого та прокурора виконувати ухвалу про дозвіл на обшук житла чи іншого володіння особи через наділення зазначених суб'єктів комплексом прав та обов'язків, наприклад, вжиття належних заходів для забезпечення присутності під час проведення обшуку осіб, права та законні інтереси яких можуть бути обмежені або порушені, визначення часу проведення обшуку, а також безпосереднім правом на прийняття рішення за наявності достатніх підстав провести особистий обшук [4, с. 141].

Таке розуміння вказаної норми, з одного боку, встановлює додаткові гарантії від свавілля оперативних підрозділів, а з іншого - обмежує законне право слідчого та прокурора, передбачене п. 5 ч. 2 ст. 36 і п. 3 ч. 2 ст. 40 КПК (а саме, доручати проведення слідчих (розшукових) дій та негласних слідчих (розшукових) дій відповідним оперативним підрозділам).

Крім того, у ч. 1 ст. 236 КПК закріплено, що «ухвала про дозвіл на обшук житла чи іншого володіння особи може бути виконана (курсив наш. - С.Д. та Д.М.) слідчим чи прокурором». Тобто в наведеному положенні відсутні будь-які прояви імперативності, а таке конструювання більш характерне для норми-дозволу. На нашу думку, для законодавчого акта, який характеризується чіткою правовою регламентацією та неможливістю подвійного тлумачення, представлене формулювання приписів ч. 1 ст. 236 КПК видається недостатньо повним і точним. Касаційний кримінальний суд у складі Верховного Суду (далі - ККС ВС) у згаданому рішенні обмежився вузьким трактуванням (або буквальним тлумаченням) цієї норми. Але таким чином нівелюється положення закону про процесуальну самостійність слідчого та прокурора як владних суб'єктів даних правовідносин.

3 огляду на викладене на противагу цьому рішенню варто привести постанову Верховного Суду України від 30 листопада 2017 р. (справа № 441/1659/15-к), який вказував на те, що особливістю кримінальних процесуальних норм, на відміну від, наприклад, кримінально-правових, є те, що їхні структурні елементи (гіпотеза, диспозиція, санкція) у переважній більшості випадків не зосереджені в одній статті КПК, а окремо викладені законодавцем у різних статтях, іноді навіть розділах, КПК України, а отже, зміст окремої норми може бути виявлено лише шляхом системного тлумачення положень КПК [5]. У контексті наведеної правової позиції слідчий, прокурор наділені правом на прийняття під час кримінального провадження будь-якого процесуального рішення, що не суперечить закону, на основі власного внутрішнього переконання. Інакше розуміння цієї норми обмежує їхнє право доручати проведення слідчих (розшукових) дій (i, зокрема, обшуку) оперативним підрозділам (п. 5 ч. 2 ст. 36 , п. 3 ч. 2 ст. 40 та ст. 41 КПК). До того ж відсутність у КПК будь-яких виключень із аналізованого законодавчого положення свідчить про абсолютний характер такого права слідчого, прокурора. Наявність же окресленої «ситуації» є суттєвим недоліком кримінального процесуального закону, оскільки таким чином порушується принцип правової визначеності, який є невід'ємним складовим елементом верховенства права. Тому законодавцеві доцільно було б звернути на це увагу та внести відповідні зміни до чинного КПК. 
Здавалося б, із прийняттям Верховним Судом вказаного вище рішення питання щодо участі оперативних підрозділів у проведенні обшуку з'ясовано, однак після його появи у правозастосовній практиці виникло ще більше проблем. Доволі часто сторона захисту, посилаючись на постанову ККС ВС від 29 січня 2019 р. (справа № 466/896/17), вказує на неможливість залучення до обшуку співробітників оперативних підрозділів, оскільки вони не є учасниками кримінального провадження у розумінні п. 25 ч. 1 ст. 3 КПК.

Зазначене питання було вирішено із ухваленням постанови Верховного Суду від 31 березня 2021 р. (справа № 727/8945/17). Так, звертаючись до Верховного Суду із касаційною скаргою, сторона захисту вказувала на те, що обшуки транспортного засобу, квартири, а також освідування особи проведені не слідчим, а оперативним співробітником ОСОБА_5. Утім, Верховний Суд не погодився з такими твердженнями захисту, оскільки з матеріалів кримінального провадження вбачається, що протоколи за результатами вказаних слідчих дій складено слідчим, який здійснював досудове розслідування, а оперуповноважений ОСОБА_5 був їх учасником, про що, відповідно, міститься відмітка у згаданих протоколах та підписи учасників слідчих дій. У ході розгляду цієї справи ККС ВС сформулював правову позицію про те, що участь оперативного співробітника під час проведення слідчим слідчої дії та виконання таким співробітником доручень слідчого не вказує на те, що ця дія проведена неуповноваженою особою, оскільки організація проведення слідчої дії, залучення її учасників, які необхідні слідчому для проведення такої дії і які, зокрема, допомагають слідчому провести слідчу дію, покладається на розсуд останнього, в межах його компетенції з урахуванням складності й обсягу слідчої дії.

Крім того, Верховний Суд відзначив, що посилання сторони захисту на постанову ККС ВС від 29 січня 2019 р. (справа № 466/896/17) є необгрунтованим, оскільки в аналізованій справі обшук був проведений працівником оперативного підрозділу на підставі письмового доручення слідчого, наданого такому працівнику в порядку ст. 40 КПК, в цій же справі, як вже було зазначено, обшуки й освідування були проведені слідчим, а працівник оперативного підрозділу лише надавав допомогу слідчому при проведенні вказаних слідчих дій та діяв під керівництвом цього слідчого [6].

У ракурсі дослідження окремих проблемних питань, пов'язаних із проведенням обшуку, не можна оминути увагою наступне. Ідеться про рішення Верховного Суду стосовно обсягу відомостей, які мають бути викладені в ухвалі слідчого судді про дозвіл на обшук.

Так, приписи ст. 235 КПК не зобов язують слідчого суддю в ухвалі зазначати прокурора чи слідчого, який буде проводити обшук, натомість названа ухвала має містити відомості про прокурора, слідчого, який подав клопотання про обшук. Зміст норм КПК не дає підстав для твердження про те, що до повноважень слідчого судді належать, крім здійснення судового контролю за дотриманням прав, свобод та інтересів осіб у кримінальному провадженні (п. 18 ч. 1 ст. 3 КПК), ще й інші, віднесені до повноважень прокурора та слідчого з організації досудового розслідування. Із системного тлумачення статей $36,40,235,236$ КПК не вбачається, що 
до компетенції слідчого судді належить визначення як конкретного слідчого або прокурора, які мають здійснювати таку слідчу (розшукову) дію, так й інших осіб, що будуть брати участь у проведенні обшуку (понятих, працівників оперативного підрозділу, спеціалістів та ін.). Таким чином, визначення в ухвалі слідчого судді конкретного слідчого або прокурора, які мають здійснювати обшук, перебуває поза межами повноважень слідчого судді з контролю за дотриманням прав, свобод та інтересів осіб у кримінальному провадженні та обмежується в цій частині перевіркою того, чи є належним суб єктом учасник кримінального провадження, який звернувся з клопотанням про проведення обшуку [7]. Отже, в даному рішенні Верховний Суд дійшов висновку про те, що ухвала про дозвіл на обшук житла чи іншого володіння особи може бути виконана прокурором, призначеним здійснювати процесуальне керівництво в порядку ст. 37 КПК, або слідчим, визначеним керівником органу досудового розслідування в порядку ст. 39 КПК.

Особливої актуальності проблема правового регулювання інституту слідчих (розшукових) дій (i, зокрема, обшуку) набула у процесі новелізації КПК України спрощеним порядком досудового розслідування окремих категорій кримінальних правопорушень. На тлі кардинальних змін до КПК, внесених Законом України № 2617-VIII від 22 листопада 2018 р., в кримінальному провадженні з’явився новий учасник - дізнавач.

Разом із тим наявна судова практика свідчить про наявність значної кількості проблемних питань, пов'язаних із діяльністю цього суб'єкта кримінальних процесуальних відносин. Фактично у чинному КПК спостерігається колізія між положеннями п. 2 ч. 2 ст. 40-1 КПК та нормами, які регламентують порядок проведення слідчих (розшукових) дій.

Так, у статті 40-1 КПК передбачено, що дізнавач уповноважений проводити слідчі (розшукові) дії та негласні слідчі (розшукові) дії у випадках, установлених КПК. Однак у главі 20 КПК «Слідчі (розшукові) дії» відсутні будь-які приписи стосовно повноважень дізнавача на їх проведення (окрім норми, закріпленої у ч. 3 ст. 233 КПК). Буквальне розуміння законодавчих положень вказаної глави КПК дозволяє стверджувати, що проведення слідчих (розшукових) дій є прерогативою лише слідчого та прокурора. Проте результати аналізу судової практики свідчать, що слідчими суддями розглядаються та вирішуються клопотання дізнавачів про дозвіл на проведення слідчих дій, які потребують попереднього отримання судового рішення, i, зокрема, обшуку. Водночас рішення, ухвалені за результатами розгляду цих клопотань, мають абсолютно протилежний зміст.

Наприклад, слідчий суддя Роменського міськрайонного суду Сумської області Машина I.M. задовольнила клопотання старшого інспектора сектору дізнання Роменського відділу поліції Головного управління Національної поліції в Сумській області Ситника Д.М., погоджене прокурором Роменської місцевої прокуратури Сухоставець 0.0., про надання дозволу на проведення обшуку у Сумському обласному державному нотаріальному архіві [8]. Як вбачається зі змісту ухвали, слідчий суддя у мотивувальній частині рішення ототожнила дізнавача зі слідчим, що видається неприпустимим, оскільки, незважаючи на схожість їхніх процесуальних повноважень, це зовсім різні учасники кримінального провадження. 
Утім, на практиці спостерігається й інший підхід до цієї проблематики. Так, ухвалою слідчого судді Рівненського міського суду Рівненської області від 17 липня 2020 р. відмовлено у задоволенні клопотання дізнавача Рівненського ВП ГУНП в Рівненській області лейтенанта поліції Горбатюка О.М. про надання дозволу про проведення обшуку у кримінальному провадженні № 12020180010002699 . Слідчий суддя, відмовляючи у задоволенні поданого клопотання, зазначив в ухвалі, що Кримінальний процесуальний кодекс України не наділив дізнавача правом звертатися до слідчого судді з клопотанням про надання дозволу на проведення обшуку.

Як відзначив Рівненський апеляційний суд: «Згідно з вимогами п. 4 ч. 2 ст. 40-1 КПК України, дізнавач уповноважений звертатися за погодженням із прокурором до слідчого судді з клопотаннями про застосування заходів забезпечення кримінального провадження, проведення слідчих (розшукових) дій, негласних слідчих (розшукових) дій. Колегією суддів, шляхом системного аналізу положень кримінального процесуального законодавства, встановлено, що обшук є слідчою (розшуковою) дією, порядок проведення якої регламентується ст. 234 КПК, що входить до Глави 20 «Слідчі (розшукові) дії» КПК. Тому колегія суддів вважає помилковим висновок слідчого судді суду першої інстанції про те, що Кримінальний процесуальний кодекс не наділив дізнавача правом звертатися до слідчого судді з клопотанням про надання дозволу на проведення обшуку» [9]. Саме таке обгрунтування відповідає правильному тлумаченню та застосуванню норм КПК і корелює із загальними засадами кримінального провадження.

Досліджуючи питання проведення обшуку під час кримінального провадження неможливо не звернути увагу на важливість відмежування обшуку від іншої слідчої дії - огляду. Сьогодні ця проблема надзвичайно актуальна. Обшук та огляд - це дві окремі за формою і різні за змістом, однак дуже схожі зовні, слідчі дії, особливо в тому випадку коли їхнім об'єктом виступає житло чи інше володіння особи. Незважаючи на відсутність у нормах КПК чіткого розмежування вказаних понять, між оглядом та обшуком у кримінальному провадженні є певні відмінності. Зокрема, О.А. Лучко виділяє такі: обов'язковість примусу та його характер, можливість проведення до внесення відомостей до ЄРДР [10, с. 119]. Вважається, що обшук завжди має примусовий характер, незалежно від того, чи надала особа згоду на проведення цієї слідчої дії. Щодо мети проведення огляду та обшуку, то мета останнього є більш конкретною - це відшукання знаряддя кримінального правопорушення або майна, яке було здобуте у результаті його вчинення, а також встановлення місцезнаходження розшукуваних осіб.

Найчастіше у правозастосовній практиці спостерігаються випадки «маскування» обшуку складенням протоколу огляду місця події. Подібні ситуації зустрічаються тоді, коли місце вчинення кримінального правопорушення знаходиться у житлі чи іншому володінні особи. За загальним правилом, встановленим у ч. 2 ст. 234 та ч. 2 ст. 237 КПК, огляд та обшук житла чи іншого володіння особи здійснюється на підставі ухвали слідчого судді. Разом із тим, зважаючи на приписи ч. 3 ст. 214 КПК, єдиною доступною слідчою дією для органів досудового розслідування до моменту внесення відомостей до Єдиного реєстру досудових 
розслідувань (далі - ЄРДР) є огляд місця події. Обшук, у свою чергу, може бути проведений лише в ході розпочатого досудового розслідування. Так, Верховний Суд у постанові від 6 жовтня 2020 р. (справа № 279/3931/18) зазначає, що обшук, який проводиться до початку досудового розслідування, є незаконним, а тому усі докази, отримані в ході даної слідчої дії, є недопустимими [11].

У зв'язку з викладеним вище для більш детального розуміння сутності обшуку та огляду місця події необхідно з'ясувати співвідношення об'єктів, щодо яких проводяться вказані слідчі дії. Так, законодавець у ст. 233 КПК чітко визначив поняття «Житло» й «інше володіння особи», але, разом із тим, чинний КПК не містить дефініції «місце події». Натомість, як підкреслює Верховний Суд, «у кримінальному процесуальному праві це місце приготування до злочину, місце безпосереднього вчинення злочину, місце виявлення слідів, засобів та знарядь злочину, предметів злочину. Відповідно, огляд місця події проводиться з метою виявлення та фіксації відомостей про ознаки та обставини вчинення кримінального правопорушення, сліди, засоби та знаряддя, з ясування механізму його вчинення, обстановки, інших обставин, які мають значення в кримінальній справі для встановлення ознак події та її юридичної оцінки як кримінального правопорушення» [12]. Тому, зазвичай, визначення цього поняття належить до дискреції слідчого, дізнавача, прокурора, які відносять той чи інший об'єкт до «місця події» на основі власного внутрішнього переконання, що не завжди може збігатися з фактичними обставинами вчиненого кримінального правопорушення.

У контексті аналізованого питання варто зауважити, що Верховний Суд неодноразово вказував на недопустимість підміни - проведення обшуку під виглядом огляду місця події, оскільки таким чином нівелюються вимоги здійснення судового контролю. Наприклад, такі правові позиції містяться у постановах від 6 жовтня 2020 р. (справа № 279/3931/18) [11], від 19 січня 2021 р. (справа № 584/27/18) [13], від 20 січня 2021 р. (справа № 127/13350/18) [14]. Крім того, Європейський суд 3 прав людини у п. 123 рішення у справі «Круглов та інші проти Росії від 4 лютого 2020 р. вкотре наголосив на тому, що будь-який захід, якщо він не відрізняється за способом виконання та практичних наслідків від обшуку, рівнозначний, незалежно від його кваліфікації за національним законодавством, втручанню у права заявників відповідно до статті 8 Конвенції [15].

3 огляду на представлену нами тематику, окремої уваги заслуговує процедура проведення особистого обшуку (обшуку особи), який визнається одним із видів обшуку як слідчої дії. Комплексний аналіз норм чинного КПК дозволяє констатувати, що особистий обшук особи може бути проведений у двох випадках: 1) під час затримання уповноваженою службовою особою (ч. 3 ст. 208, ч. 6 ст. 298-2 КПК) та 2) під час обшуку житла чи іншого володіння особи (ч. 5 ст. 236 КПК). У свою чергу, недосконалість правового регулювання процедури особистого обшуку обумовила підвищений інтерес науковців та практиків до цієї проблематики [16, с. 255-261]. Так, у чинному КПК не міститься цілісної статті, присвяченої обшуку особи, i, як наголошує Верховний Суд, обшук особи фактично не є окремою слідчою дією, а поглинається такою дією, як затримання чи обшук житла [17]. 
Більше того, Верховний Суд в ухвалі від 16 лютого 2021 р. (справа № 204/6541/16-к) зауважив, що затримання і особистий обшук затриманої особи може відбуватися до внесення відомостей у ЄРДР. Як вже зазначалося, затримання без дозволу суду є непередбачуваною подією, тому вимога до органу правопорядку внести відомості до ЄРДР до такої події є нереалістичною. Таким чином, на думку колегії, внесення чи невнесення відомостей до ЄРДР на час затримання та особистого обшуку особи не може бути умовою законності затримання i, відповідно, фактором, який визначає допустимість доказів, отриманих під час такого обшуку.

Колегія звертає увагу, що особистий обшук особи під час затримання визнається Верховним Судом законним. Відповідно до судової практики ця слідча дія вважається інтегральною частиною процесу затримання особи в порядку статті 208 КПК і відображається в протоколі затримання [18].

Ще однією особливістю особистого обшуку є те, що КПК передбачає розширений суб'єктний склад для його проведення, порівняно з обшуком житла чи іншого володіння особи. Верховний Суд у вищенаведеному рішенні наголосив на тому, що стаття 208 КПК надає повноваження затримати особу, підозрювану у вчиненні злочину, «уповноваженій службовій особі». Хоча КПК України не містить спеціального визначення цього терміна, однак із формулювань інших положень КПК вбачається, що «уповноважена службова особа» вживається разом з термінами «слідчий», «прокурор», «дізнавач». Це призводить до висновку, що використаний термін охоплює й інших осіб, яким відповідно до закону надані повноваження проводити затримання, але які не $\epsilon$ «слідчим», «прокурором» або «дізнавачем». Зазначений термін включає поліцейських патрульної або іншої служби поліції, яким такі повноваження надано статтею 37 Закону «Про Національну поліцію», військовослужбовців Служби правопорядку, уповноважених на затримання Законом «Про Військову службу правопорядку у Збройних Силах України», службових осіб органів Державної прикордонної служби України тощо [18].

Особистий обшук як вид процесуального примусу супроводжується істотним обмеженням прав особи/осіб. Із позиції міжнародно-правових актів у сфері захисту прав людини обмеження таких прав є законними, якщо вони мають правову основу. За загальними правилами, викладеними у ч. 2 ст. 234 КПК, обшук має проводитися лише на підставі ухвали слідчого судді. Із точки зору формальної логіки особистий обшук, як один із його різновидів, підлягає попередньому судовому контролю. Водночас системний аналіз нормативних положень КПК вказує на те, що у ньому міститься вичерпний перелік процесуальних дій, які проводяться за ухвалою слідчого судді. Чинний кримінальний процесуальний закон не визначає порядку розгляду слідчим суддею клопотань про надання дозволу на обшук особи/осіб та постановлення відповідних ухвал. При цьому не можна не відмітити той факт, що всупереч відсутності у КПК прямої вказівки на отримання ухвали слідчого судді, непоодинокими є випадки звернення представників органів досудового розслідування з клопотаннями про дозвіл на особистий обшук.

Так, наприклад, слідчий суддя Ленінського районного суду м. Миколаєва Захарченко Д.В. відмовив у задоволенні клопотання старшого слідчого Ленін- 
ського ВП ГУНП в Миколаївській області Павлова І.А. про проведення особистого обшуку ОСОБА_3. Дослідивши надані матеріали, слідчий суддя вважає, що згідно зі статтями 234-236 КПК слідчим суддею, судом не вирішується питання про проведення обшуку особи [19].

Разом із тим доволі значна кількість слідчих суддів дотримуються протилежної думки, задовольняючи такі клопотання, виходячи при цьому із загальних підстав для проведення обшуку. Наприклад, ухвалою слідчого судді Печерського районного суду м. Києва від 28 листопада 2018 р. задоволено клопотання старшого слідчого в ОВС ГСУ НП у Харківській області та надано дозвіл на обшук особи ОСОБА_1 у рамках кримінального провадження № 22018000000000079 [20].

У спробі вирішити дане дискусійне питання, ми цілком погоджуємось із думкою С. Л. Лисаченка, який вважає, що судовий контроль за особистим обшуком затриманої особи ніби переноситься на більш пізній етап, коли органи розслідування звертаються до слідчого судді для застосування до особи запобіжного заходу, зокрема, тримання під вартою. У ході цієї процедури слідчий суддя перевіряє законність затримання, здійснення особистого обшуку та інших процесуальних засобів для констатації наявності чи відсутності обгрунтованої підозри у вчиненні злочину [21, с. 55]. У протилежному разі, коли слідчим, дізнавачем, прокурором не було подано відповідного клопотання, особа повинна бути негайно звільнена.

Стосовно ж особистого обшуку осіб, які перебувають в житлі чи іншому володінні, то, якщо є достатні підстави вважати, що вони переховують при собі предмети або документи, які мають значення для кримінального провадження, то допустиме обмеження права на особисту недоторканність в даному випадку легітимоване ухвалою про дозвіл на обшук житла чи іншого володіння особи. Відповідно до ч. 5 ст. 236 КПК рішення про проведення обшуку особи належить до виключної компетенції слідчого, прокурора. Таким чином, кримінальний процесуальний закон не передбачає отримання ухвали слідчого судді про дозвіл на особистий обшук. А надмірний формалізм сприятиме затягуванню строків досудового розслідування. Крім того, названий кодифікований акт передбачає досить ефективні гарантії від свавільного обмеження конституційних прав особи.

Останнім часом особливе занепокоєння викликають проблеми, пов'язані з обмеження прав і свобод особи під час проведення обшуку. Контекстно нагадаємо, що утвердження і забезпечення прав та свобод людини є головним принципом правової держави. Захисту та охороні прав учасників кримінального провадження відводиться чи не найбільш важливе місце в системі вітчизняного кримінального процесуального законодавства.

Відтак гарантоване статтею 59 Конституції України право людини на професійну правничу допомогу має бути ключовим елементом на будь-якому етапі обшуку житла чи іншого володіння особи. Адже наявність у адвоката знань про належний порядок проведення обшуку є надійною гарантією забезпечення режиму законності й ефективного захисту прав, свобод та інтересів клієнта. Як підкреслив Конституційний Суд України у рішенні № 23-рп/2009 від 30 вересня 2009 р., положення статті 59 Конституції України є нормою прямої дії й особа не може бути обмежена в його реалізації [22]. 
Разом із тим формулювання КПК із приводу участі адвоката в проведенні обшуку залишаються неоднозначними, особливо в тому випадку, коли клієнт не набув процесуального статусу учасника кримінального провадження. Цілком очевидно, що присутність адвоката складно забезпечити в мінімальні терміни, тому, як правило, адвокат фізично не може бути присутнім на обшуку від самого його початку. Як свідчать висновки науковців та узагальнення судової практики, незважаючи на встановлений обов'язок слідчого, прокурора допустити адвоката до обшуку на будь-якому етапі його проведення, зазвичай, така слідча дія проводиться до моменту прибуття цього суб'єкта правовідносин. Тлумачення положень ст. 236 КПК у вузькому розумінні надає можливість слідчому, прокурору провести обшук і до прибуття адвоката. Наразі відсутні будь-які роз'яснення Верховного Суду з даного питання, внаслідок чого відсутній правовий механізм оскарження таких дій представників органів досудового розслідування та прокуратури.

Убачається, що розгляд цієї проблеми необхідно здійснювати під кутом зору забезпечення суб'єктами проведення обшуку розумного балансу між повагою до приватного життя особи та його реалізацією в поєднанні з досягненням поставленої мети. Для суб’єктів проведення обшуку ця слідча дія є заздалегідь спланованою тактичною операцією, спрямованою на отримання нових та/або перевірку вже отриманих доказів. Тому, на думку багатьох слідчих, чекати на прибуття адвоката - означає завчасно приректи обшук на невдачу з різних причин: за цей час може бути знищена доказова інформація, приховані сліди кримінального правопорушення, будуть реалізовані спроби осіб покинути місце проведення обшуку тощо. Відтак втрачається головна умова успішного проведення слідчої дії - раптовість. Однак подібні міркування не можна вважати правильними, адже суб'єкти, які здійснюють обшук, мають передбачене законом право заборонити всім присутнім особам залишати місце проведення обшуку до його закінчення та вчиняти будь-які дії, що заважають проведенню обшуку (ч. 3 ст. 236 КПК).

Водночас для осіб, у житлі чи іншому володінні яких проводиться обшук, це доволі неочікувана подія. Крім того, останнім часом у суспільстві сформувався сталий стереотип проявів свавілля з боку представників різних правоохоронних відомств. Якслушноізцьогоприводу зауважує О.В. Керевич, слідчі, прокуроричасто не надають належного значення законності й обгрунтованості обшуку, при цьому допускають істотні порушення вимог процесуального законодавства, нехтують моральністю під час проведення слідчих дій [23]. У такому розумінні, на думку переважної більшості осіб, які потрапляють в орбіту кримінального судочинства, будь-які вказівки слідчого, прокурора під час обшуку повинні виконуватись ними безумовно і беззаперечно. Попри виконання обов'язку щодо роз'яснення присутнім під час обшуку особам їхніх прав, без участі адвоката навряд чи можна говорити про здатність останніх повною мірою усвідомлювати сутність цієї слідчої дії.

До того ж видається не зрозумілою позиція законодавця щодо встановлення «привілейованого» трьохгодинного строку на прибуття адвоката для проведення особистого обшуку. Тобто слідчий, прокурор не мають права проводити обшук особи, яка вимагає участі у ньому адвоката до моменту його прибуття. Водночас неприбуття останнього протягом трьох годин не перешкоджає проведенню цієї 
слідчої дії. Закон однаково охороняє право на особисту недоторканність та право на недоторканність житла чи іншого володіння будь-якої особи. Зокрема, ст. 8 Конвенції про захист прав людини і основоположних свобод комплексно декларує права кожного на повагу до свого приватного і сімейного життя, до житла і кореспонденції. Така гарантія законності повинна бути встановлена і для обшуку особи. Адже тільки спеціально підготовлена особа, адвокат, здатна попередити можливі порушення чи незаконні обмеження прав і свобод людини з боку органів досудового розслідування та прокуратури. У такий спосіб буде повністю реалізоване завдання кримінального провадження - «щоб жодна особа не була піддана необгрунтованому процесуальному примусу» .

Висновки. Виходячи з вищевикладеного, можна констатувати: одним із пріоритетних напрямів перебудови галузі кримінального процесуального права має стати створення цілісної та дієвої системи гарантій прав і свобод осіб, які залучаються до сфери кримінального судочинства, під час проведення слідчих (розшукових) дій. У зв'язку із цим у роботі сформульовані обгрунтовані пропозиції, спрямовані на оптимізацію та вдосконалення нормативного регулювання процедури проведення обшуку житла, іншого володіння особи й особистого обшуку. Неповнота правової регламентації цього фронту діяльності потребує якісно нових підходів та внесення певних змін і доповнень до вітчизняного кримінального процесуального законодавства та може бути предметом подальших наукових досліджень.

\section{Jimepamypa}

1. Черняк Н.П. Особливості проведення обшуку за кримінальним процесуальним законодавством України. Науковий вісник Дніпропетровського державного університету внутрішніх справ. 2018. № 4(97). С. 148-152.

2. Справа «Класс та інші проти Німеччини» (Case of Klass and Others v. Germany) від 6 вересня 1978 року : Рішення Європейського суду з прав людини URL: https://zakon.rada.gov.ua/laws/ show/980_093\#Text (дата звернення: 25.04.2021р.).

3. Судова справа № 466/896/17 : Постанова Касаційного кримінального суду Верховного Суду від 29.01.2019 року URL: https://reyestr.court.gov.ua/Review/79601140 (дата звернення: 25.04.2021 p.).

4. Комарова М.В. Правові та організаційні засади обшуку у кримінальному провадженні : дис ... канд. юрид. наук : 12.00 .09 / Марта Василівна Комарова. Київ, 2019. 256 с.

5. Судова справа № 441/1659/15-к : Постанова Верховного Суду України від 30.11.2017 року. URL: https://reyestr.court.gov.ua/Review/70764889\# (дата звернення: 25.04.2021 p.).

6. Судова справа № 727/8945/17 : Постанова Касаційного кримінального суду Верховного Суду від 31.03.2021 року. URL: https://reyestr.court.gov.ua/Review/96071404?fbclid=IwAR2qKOWnmH4eeKKkWUBEHRdiRz6Svjm4lyBAoajZyI6E1ST7FNYYy3nw-M (дата звернення: 25.04.2021р.).

7. Судова справа 263/10353/16-к : Постанова Касаційного кримінального суду Верховного Суду від 17.02.2021 року. URL: https://reyestr.court.gov.ua/Review/95042547?fbclid=IwAR06Pvm2r0FeM gPcBumI-om2wavDSA3YhJlr2GliiGaHVyls4i8q7Y0VcAw (дата звернення: 25.04.2021р.).

8. Судова справа № 585/2968/17 : Ухвала Роменського міськрайонного суду Сумської області від 03.12.2020 pоку. URL: https://reyestr.court.gov.ua/Review/93321091 (дата звернення: 05.05.2021 p.).

9. Судова справа № 569/11395/20 : Ухвала Рівненського апеляційного суду від 05.08.2020 року. URL: https://reyestr.court.gov.ua/Review/90905517 (дата звернення: 05.05.2021р.).

10. Лучко О.А. Співвідношення огляду з обшуком у кримінальному досудовому провадженні. Європейські перспективи. № 3. 2020. С. 117-121.

11. Судова справа 279/3931/18 : Постанова Касаційного кримінального суду Верховного Суду від 06.10.2020 року. URL: https://reyestr.court.gov.ua/Review/92093240 (дата звернення: 25.04 .2021 р.).

12. Судова справа № 281/422/18: Постанова Касаційного кримінального суду Верховного Суду від 17.03.2021 року. URL: https://reyestr.court.gov.ua/Review/95708347 (дата звернення: 10.05.2021р.). 
13. Судова справа № 584/27/18 : Постанова Касаційного кримінального суду Верховного Суду від 19.01.2021 року. URL: https://reyestr.court.gov.ua/Review/94452942 (дата звернення: 10.05.2021 р.).

14. Судова справа № 127/13350/18 : Постанова Касаційного кримінального суду Верховного Суду від 20.01.2021 року. URL: https://reyestr.court.gov.ua/Review/94394492 (дата звернення: 10.05.2021 р.).

15. Справа «Круглов та інші проти Росії» (Case of Kruglov and others v. Russia) (заява № 11264/04) від 4 лютого 2020 року : Рішення Європейського Суду з прав людини. URL: https://www.echr.com.ua/ translation/sprava-kruglov-ta-inshi-proti-rosi\% D1\% 97/ (дата звернення: 25.04.2021 р.).

16. Шаренко С.Л. Теоретико-прикладні основи діяльності слідчого судді в кримінальному провадженні : монографія. Харків : Право, 2021. 480 с.

17. Судова справа № 755/6685/17 : Постанова Касаційного кримінального суду Верховного Суду від 13.02.2020 року. URL: https://reyestr.court.gov.ua/Review/87760561 (дата звернення: 05.05.2021 p.).

18. Судова справа 204/6541/16-к : Ухвала Касаційного кримінального суду Верховного Суду від 16.02.2021 року. URL: https://reyestr.court.gov.ua/Review/95533196 (дата звернення: 05.05.2021 p.).

19. Судова справа 489/6611/15-к : Ухвала Ленінського районного суду м. Миколаєва від 29.02.2016 року. URL: https://reyestr.court.gov.ua/Review/56211946 (дата звернення: 05.05.2021 р.).

20. Судова справа 757/59152/18-к : Ухвала Касаційного кримінального суду Верховного Суду від 25.04.2019 року. URL: https://reyestr.court.gov.ua/Review/81573920 (дата звернення: 05.05.2021 p.).

21. Лисаченко С.Л. Обмеження та порушення прав і свобод під час проведення особистого обшуку. Recht der Osteurop ischen Staaten. 2019. № 3. С. 54-58.

22. Рішення Конституційного Суду України у справі за конституційним зверненням громадянина Голованя Ігоря Володимировича щодо офіційного тлумачення положень статті 59 Конституції України (справа про право на правову допомогу) № 23-рп/2009 від 30.09.2009 року. URL: https://zakon. rada.gov.ua/laws/show/v023p710-09\#Text (дата звернення: 25.04.2021р.).

23. Керевич О.В. Тактичні та процесуальні особливості проведення обшуку житла чи іншого володіння особи. Актуальні проблеми держави та права. 2014. № 71. С. 379-385.

\section{Анотація}

Давиденко С. В., Мавдрик Д. О. Проблеми вдосконалення правового регулювання процедури проведення обшуку слідчим, дізнавачем, прокурором. - Стаття.

У статті досліджені окремі проблеми нормативно-правового регулювання процедури проведення обшуку як різновиду слідчих дій під час досудового розслідування, що найчастіше виникають у правозастосовній практиці, в контексті потенційної гармонізації вітчизняного кримінального процесуального законодавства 3 європейськими стандартами у сфері захисту прав і свобод людини, що свідчить про актуальність даного дослідження.

У представленій науковій роботі детально проаналізовані положення вказаного правового інституту, присвячені суб'єктному складу осіб, уповноважених на проведення обшуку (як одного з основних способів збирання необхідної доказової інформації) під час досудового розслідування, а також відповідні прецеденти Європейського суду з прав людини із заданої тематики. На підставі грунтовного вивчення кримінального процесуального законодавства України та наявної судової практики 3'ясовані критерії розмежування таких слідчих дій як огляд і обшук, та наголошено на неприпустимості проведення обшуку в житлі чи іншому володінні особи під видом огляду (в тому числі огляду місця події).

Інтегральною частиною роботи є характеристика правових підстав та особливостей процесуального порядку проведення обшуку особи в контексті дотримання такої засади кримінального провадження, як забезпечення права свободу та особисту недоторканність. У ході наукового дослідження помітний акцент зроблено на конституційному праві особи (в житлі або іншому володінні якої проводиться обшук) на професійну правничу допомогу, а також на специфічному алгоритмі його роз'яснення та реалізації.

Сформульовані у статті пропозиції спрямовані на вдосконалення окреслених положень чинного кримінального процесуального законодавства України в частині правового регулювання процедури проведення обшуку в житлі чи іншому володінні особи, а також обшуку певної особи, яка перебуває у відповідному приміщенні під час виконання ухвали слідчого судді про дозвіл на проведення обшуку. Надані обгрунтовані рекомендації щодо оптимального застосування окремих норм національного законодавства, які свідчать про практичне значення результатів проведеного дослідження.

Ключові слова: слідчі дії, обшук, слідчий, дізнавач, прокурор, слідчий суддя, обшук особи. 


\section{Summary}

Davydenko S. V., Mavdrik D. O. Problems of improving the legal regulation of the search procedure by an investigator, coroner, prosecutor. - Article.

The article examines some problems of legal regulation of the search procedure, as a kind of investigative actions during pre-trial investigation, which most often occur in law enforcement practice, in the context of potential harmonization of domestic criminal procedure legislation with European standards in the field of human rights and freedoms, indicates the relevance of this study.

The presented scientific work analyzes in detail the provisions of this legal institution, devoted to the subjective composition of persons authorized to conduct a search (as one of the main ways to gather the necessary evidence) during the pre-trial investigation, as well as relevant precedents of the European Court of Human Rights. Based on a thorough study of the criminal procedure legislation of Ukraine and existing case law, the criteria for distinguishing such investigative actions as inspection and search were clarified, and the inadmissibility of a search of a home or other property of a person under inspection (including inspection of the scene) was emphasized.

An integral part of the work is the characterization of the legal grounds and features of the procedural procedure for conducting a search of a person in the context of compliance with such a principle of criminal proceedings as ensuring the right to liberty and security of person. The research focuses on the constitutional right of a person (whose home or other property is being searched) to professional legal assistance, as well as on a specific algorithm for its explanation and implementation.

The proposals formulated in the article are aimed at improving the outlined provisions of the current criminal procedure legislation of Ukraine in terms of legal regulation of the search procedure in the home or other property of a person, as well as search of a person, who is in the room during the search judge. Substantiated recommendations are given on the optimal application of certain norms of national legislation, which indicate the practical significance of the results of the study.

Key words: investigative actions, search, investigator, coroner, prosecutor, investigating judge, search of a person. 